\title{
Panorámica teatral y rasgos significativos de la obra de Miguel Palacios
}

\section{Carmen Arribas Castillo}

\section{(2) OpenEdition \\ 1 Journals}

Edición electrónica

URL: https://journals.openedition.org/cher/1105

DOI: $10.4000 /$ cher. 1105

ISSN: 2803-5992

\section{Editor}

Presses universitaires de Strasbourg

\section{Edición impresa}

Fecha de publicación: 11 julio 2019

Paginación: 89-103

ISBN: 979-10-344-0046-1

ISSN: 1968-035X

Referencia electrónica

Carmen Arribas Castillo, «Panorámica teatral y rasgos significativos de la obra de Miguel Palacios», reCHERches [En línea], 22 | 2019, Publicado el 04 octubre 2021, consultado el 18 noviembre 2021. URL: http://journals.openedition.org/cher/1105 ; DOI: https://doi.org/10.4000/cher.1105 


\title{
Panorámica teatral y rasgos significativos de la obra de Miguel Palacios
}

\author{
Carmen Arribas Castillo $0^{1}$
}

$\mathrm{E}^{1}$ 20 de marzo de 1970 nace Miguel Palacios en Málaga. En la aproximación que hacemos a su figura y a sus aportaciones al hecho teatral, encontramos que su actividad dramatúrgica desde 1994 hasta el día de hoy abarca una cincuentena de obras, la mayoría caracterizadas por un alto compromiso político, social y humano. Su producción, diversa en géneros y vías expresivas, está estructurada en varias etapas que corresponden a las distintas épocas creativas por las que ha pasado el autor.

A principios de los años 90, Palacios lee concienzudamente a los grandes autores clásicos, Shakespeare, Góngora y Calderón serán sus predilectos, de ahí que algunas de sus obras de estilo realista pero grotesco en forma y contenido, nos remitan a la fiesta barroca, al Teatro del Mundo, al teatro fiesta. Es un tiempo en el que recibe una gran influencia tanto de la literatura clásica, como del cine y sobre todo de la poesía ${ }^{2}$, destacando autores como Jesús Aguado, con quien tuvo la oportunidad en 1993 de realizar un taller de poesía en la Universidad de Málaga, o Chantal Maillard. De la poesía el autor aprendió la sutileza de la palabra.

Su primer contacto con el teatro, como actor, sucede en el aula de teatro de la Universidad de Málaga, a cargo de Chencho Ortiz. Por estos años, Palacios también encuentra motivaciones teóricas en Artaud y manifiesta una clara influencia de Beckett y Arrabal. Como espectador, presencia representaciones rompedoras: Danzón de perras de Luis Riaza - a cuyos ensayos tuvo la oportunidad de asistir-, Horror Vacui ${ }^{3}$, de Romero Esteo o Dos disparos, tres leones de Sara Molina. Esto le estimula a ver el teatro desde una perspectiva más innovadora y rupturista impulsándole a iniciar lo que consideramos su primera

1 Carmen Arribas Castillo, Universidad Rey Juan Carlos.

2 En 1995 el autor publica el poemario La otra orilla del carbono, Málaga, Árbol de Poe.

3 El autor participa en dicho montaje teatral como ayudante de producción, trabajo que abandona pocos días antes del estreno por desavenencias con el director de la obra. 
etapa, denominada "experimentación y aprendizaje teatral" de los recursos de la escritura dramática.

En 1994 escribe El tren (metamorphosis / curso intensivo de supervivencia), un ribeteado de escenas alrededor de un monólogo sobre el cambio de siglo, a la que le sigue Los caballos no comen chocolate (1994), obra estructurada en 4 cuadros, basada en la vida y obra de Toulouse Lautrec, "personaje" que le sirve al autor para evidenciar los múltiples complejos que caracterizan al ser humano. En esta obra aparece claramente la influencia de Chaplin y de las artes plásticas.

A partir de este momento, inicia su segunda etapa dedicada a la tragedia delirante ${ }^{4}$. Una tragedia expresada a través del delirio desde una forma grotesca, un teatro elaborado desde la complejidad estructural, que ofrece una visión expandida de la realidad y que sitúa al autor en un camino de máxima libertad expresiva mostrando una escritura teatral notoriamente comprometida, donde los recursos teatrales son organizados a merced de sus necesidades y donde presenta una realidad poético-simbólica que vulnera la lógica.

Curiosamente, sus tragedias delirantes han sido asociadas con la grotescomaquia de Romero Esteo por su tendencia renovadora y ciertamente radical. Sin embargo y a pesar de conocer a dicho autor en esa época, Palacios afirma que no cree que fuera una influencia consciente en ese tiempo para su escritura, aunque lo que sí le influyó, y mucho, fue su visión del mundo (Arribas 2018). Destacar que la técnica dramática utilizada en la tragedia delirante es elogiada como muestra temprana de la habilidad del dramaturgo y en ella observamos elementos que también aparecen en la grotescomaquia.

A caballo entre las dos primeras etapas están Mascarada de San demonio mártir y la vieja pelleja Micaela y La perversa encarnación de Lilo el lila.

Mascarada de San demonio mártir y la vieja pelleja Micaela también denominada -El cóctel de los demonios-, es escrita en 1995 y estrenada un año después. En la primera parte de la obra, observamos pinceladas puramente asociadas al grotesco aunque algo más burdo y menos complejo que el que nos muestra en obras como Muñecos de Buridán o La perversa encarnación de Lilo el lila.

Los personajes reflejan una gran influencia del comic y la caricatura, algunos como la vieja o el doctor nos remiten a los títeres de cachiporra. La farsa queda reflejada en el personaje de Ambrosia cual títere de cuerda; y Micaela cuando rejuvenece y nos da las instrucciones para capturar a un demonio, deja entrever un simbolismo oscuro y misterioso que nos remite al campo de la espiritualidad:

[...] lo primero que debes hacer es inflar tus pulmones. Mírate por dentro entonces. Descubrirás extensos bosques y callejones oscuros. Por mucho que te

4 Dichas obras recrean universos poéticos en donde el autor cuestiona las relaciones personales y sobre todo el concepto del individualismo que nos remite a los filósofos presocráticos y que también, es entendido aquí, como una aproximación a la metafísica, al ser y sus principios. De ahí que Palacios muestre una gran preocupación por lo humano y lo cuestione, situándolo en el género de la tragedia. 
atraigan, deja de lado los bosques... ¡Directo a los callejones!, es allí donde moran los demonios. Son tan astutos, se camuflan entre las sombras para hacernos creer que se han marchado. No te dejes engañar, siguen ahí, agazapados en lo más recóndito de ti, representando un personaje con tu mismo rostro, que la mayoría de las veces todos, incluso tú, llaman por tu nombre (Palacios 1995b: 11).

Sin embargo, en la última parte de la obra, el autor utiliza el naturalismo para potenciar la caída de las máscaras en los personajes y mostrar la verdad que existe en cada uno de ellos, desvelando a su vez, el argumento de la obra.

Aquí, Palacios utiliza todos los recursos teatrales posibles, barroquismo en la escena permitiendo y exigiendo al actor pasar por múltiples registros. En sus palabras, "para mí el teatro era poesía tridimensional" (Arribas 2018), poesía que le sirve para crear ambientes y atmósferas repletas de imágenes y en donde la luz, según reflejan las acotaciones de la obra, es integrada como elemento potenciador de la acción y de la escena resultando ser tan importante como el texto o el actor. La violencia física aporta dinamismo y animalidad.

A su vez, muestra un gran trabajo de estructura, utiliza el teatro dentro del teatro, tramas ocultas, el efecto sorpresa en los sucesos con la intención de provocar la hilaridad en el público en todo momento así como la búsqueda de la catarsis, ligada a la catástrofe, mostrando la esencia de la tragedia.

Los temas más significativos que aparecen en esta etapa son: la castración provocada por la religión, la crisis del aparato político, la búsqueda de la espiritualidad a través de la doma del demonio interior, el cuestionamiento de nuestra propia percepción de la realidad, la necesidad de una lucha social capaz de romper nuestro sometimiento a los grandes elementos operantes y de una lucha individual, más comprometida, que permita que el individuo evolucione y se transforme a sí mismo, pudiendo mejorar su realidad. En esta obra confluyen las influencias de Brecht y de Artaud.

La perversa encarnación de Lilo el lila ${ }^{5}$ (1995) escrita paralelamente con Mascarada..., es una parábola de la sociedad neoliberal que en lo profundo sigue la estructura del vía crucis, en la que dos hermanos se escapan de casa para romper con la tradición y descubrir el mundo, un mundo neoliberal que los acaba devorando a ambos. Sobresale el uso que el autor otorga a la palabra dominada a través de la poesía, un recurso que le permite a su vez ir creando atmósferas sugerentes con imágenes de gran plasticidad para construir un calvario, reflejo de la sociedad contemporánea.

En Maruja, asesina de mosquitos, ratas, torturadores y verdugos ${ }^{6}$ (1995) utiliza un grotesco más poético para hablarnos del sacrificio y el trabajo de las amas de casa, un trabajo nada valorado en esta sociedad kafkiana que hemos

5 Esta obra fue finalista en 1998 en la II edición del Concurso de Textos Teatrales para jóvenes autores andaluces Miguel Romero Esteo.

6 Estrenada en el Teatro Góngora de Córdoba el 23 de febrero del 2018 y en cuyo estreno se colgó el cartel de "agotadas todas las localidades". Éxito rotundo de crítica y público. 
construido (Díaz 2018). Desde su cotidianidad, dominada por la angustia existencial, Maruja nos confiesa:

[...] lo cotidiano son un montón de platos por fregar, una comida por hacer, una cesta de ropa que planchar: un placebo; una forma de olvidarme de mí misma... Me han embargado el cuerpo, y ni me he enterado. Me han expropiado los sueños y ni los he visto venir. A veces desearía suicidarme, pero tengo miedo. Me aterra pensar que ya estoy muerta... (Palacios 1995c: 22).

A través de la sorpresa y el desarrollo de escenas inesperadas que nos narran acontecimientos terribles e hilarantes, el autor deja asomar al personaje universal, Maruja, un alegato en favor de la mujer que dedica 24 horas diarias al cuidado de su familia sin recibir nada a cambio.

En 1996 escribe Muñecos de Buridán, una obra grotesca llevada a escena en el 2011 por la compañía malagueña Teatro Línea 6. Eminentemente política, nos habla del arte de gobernar, de tomar el poder, de conservarlo y utilizarlo, "Al rebaño desorientado hay que dirigirlo... Si supiese la verdad reinaría el caos... el pánico... se volverían locos... sería imposible mantener nuestro sistema... Todo el mundo comenzaría a pensar" (Palacios 1996: 34-35). Por otro lado, el autor parece recordarnos, con absoluta convicción, que si no empezamos a recapitular y educar conforme a las bases de una sociedad virtuosa, lo que podemos esperar no es más que las consecuentes corrupciones y traiciones a las que estamos sometidos por que como afirma Ivo: "Somos las migajas del banquete universal" (Ibídem: 81).

Los personajes-muñeco, enclaustrados, solos y desamparados, sueñan con la libertad, la felicidad y sus derechos, algo inalcanzable para ellos a no ser que controlen la Caja de los Tiempos. Con ella pueden decidir cuándo es de día y cuándo es de noche, por lo tanto, el que posee la Caja de los Tiempos tiene el poder. Ante esta realidad Ivo cuestiona: “Quién reunirá el valor para renunciar al mundo que le legaron, y abandonar para siempre la caja? Lo que he visto y he vivido hace de mí lo que soy" (Ídem). Entre los recursos del juego, bailes y canciones, los personajes luchan laboriosamente por un cambio sustancial en sus vidas que nunca llega, solo les queda esperar al "mañana" para poder encontrar la salida, un mañana que es igual al hoy, donde la historia se repite y la acción de los que quedan sigue una inercia circular como el giro de las agujas de un reloj.

En el final de la obra, el autor deja patente su descrédito ante cualquier cambio social trascendente. Lo manifiesta a través de Pitiminí, cuando Marillena le confiesa su temor ante el nuevo orden: "Marillena: Oye, Pitiminí... ¿No te parece que esto va a ser máh de los mihmo? / Pitiminí: ¡Shhhhhhht! ¡Calla y duerme, Marillena! ¡Calla y duerme!” (Palacios 1996: 87)

Más tarde, tanto en La puerta, los cuervos, la tostadora, los cuernos y el bufón cabezón cara de melón ${ }^{7}$ (1996) como en Banquete para hienas y mariposa (1997), escritas al unísono, el autor alcanza un dominio de expresión propio. Nuevos

7 Esta obra recibió una Mención Especial del Jurado en 1997 en el Concurso de Textos Teatrales para jóvenes autores andaluces Miguel Romero Esteo. 
recursos teatrales son utilizados en la escritura como el empleo de diálogos paralelos en el caso de La puerta..., o la estructura algebraica del Banquete.

En 1997 escribe El viento del norte en el laberinto de las puertas, un homenaje a Escorial ${ }^{8}$ de Michel de Ghelderode donde refleja una fortísima influencia de la escritura de Luis de Góngora, con ella cierra su segunda etapa.

A partir de aquí, Palacios se cuestiona dónde situarse como autor dramático y reflexiona sobre cuál es el significado del compromiso en un autor, para qué tipo de público escribir y por qué. Duda si atender a lo social, a lo humano o personal. Lo que sí tiene claro es que es un tiempo donde urge romper con la lógica imperante para dejar al ser humano desarmado frente al abismo y ver cómo se desenvuelve en estructuras más abstractas, más propiamente posdramáticas dentro del campo teatral. Romper con la tradición y crear algo nuevo será su objetivo ya que, en gran medida, el autor sabe que así obliga al espectador a cuestionarse, le empuja a posicionarse intelectualmente y siembra en él la duda, como hacía Müller, para otorgarle a su vez la decisión de elegir a dónde ir. Estas dos vías, la social y la humana, están presentes en casi toda su tercera etapa, una producción mucho más ecléctica y donde las obras no están cohesionadas, de ahí que escriba comedia realista, épica, posdramática, grotescoexpresionista, etc.

En octubre de 1998, seleccionado por el Centro Andaluz de Teatro, Palacios viaja a Edimburgo para participar en "Colours of the Chameleon", un encuentro de jóvenes autores europeos organizado por el Traverse Theatre con el apoyo del British Council. Su interés por las artes plásticas le lleva a descubrir a múltiples artistas, entre los que destaca el máximo exponente tanto del arte figurativo como de la deformación pictórica, Francis Bacon. Inspirándose en su pintura, Palacios escribe Pequeño estudio para un retrato, un texto que evoca imágenes de gran impacto para el lector-espectador. De hecho, esta es su primera obra posdramática, aunque la escribe sin ser consciente de ello. Estructurada en 20 pasajes de diferente extensión y con el nombre de los cuadros del pintor como epígrafe -Tryptych Inspired by the Oresteia of Aeschylus, 1981; Three Studies of the Human Head, 1953; Oedipus and the Sphinx after Ingres, 1983; Study after Velazquez's Portrait of Pope Inocent X, 1953; Figure with Meat, 1954...- retrata la angustia existencial del hombre contemporáneo sometido a los designios del azar y del destino. Una obra cuyo montaje es llevado a escena por su compañía Teatro del Vacío y viaja hasta Roma para participar en la Bienal de Arte Mediterráneo en junio de 1999.

Los Pequeños rituales ${ }^{9}$ (El paraíso terrenal, El día que me quieras, El almuerzo familiar, Serenos y El muro) fueron escritos durante su estancia en Córcega -

8 Palacios también dirige Escorial y la estrena en el teatro Cánovas de Málaga en 1998.

9 Algunas de estas piezas breves fueron representadas por la compañía Teatro del Vacío en Cuba Café, Málaga, un local dedicado a la música cubana, en el que también se programaba música, teatro, danza y poesía. Palacios llevó su dirección artística durante el verano del año 2000. 
entre noviembre de 1998 y mayo de 1999. Es un conjunto de 5 piezas breves que están enmarcadas en el paradigma del ritual, son las primeras obras cortas que escribe el autor, influenciado por su experiencia en el Traverse Theatre.

El paraíso terrenal, una crítica brutal al mundo neoliberal a través de la conversación de dos jóvenes japoneses sobre la posibilidad de emigrar a EEUU justo antes de ser aniquilados por la bomba atómica: "Seremos americanosamericanos-seremos libres-libres-en América-en América-¡Mira!-¿Qué?-¡Una estrella fugaz!-¡Qué suerte!-Los dragones se despiden de nosotros-Pidamos juntos un deseo" (Palacios, 1988: 4).

El día que me quieras, cuya temática, centrada en la mujer, está relacionada con la autoestima y necesidad de quererse a sí misma para que alguien nos quiera: "Ella: Moriría amarrada a tu cintura si ese fuese tu deseo. Él: Aún no ha muerto nadie que te importe, para ti morir son cinco letras. Ella: Cinco letras en tres noches ¡déjame morir a tu lado!” (Palacios 1998: 4).

El almuerzo familiar, es el rito de la presentación del novio a la familia de la novia, con la particularidad de que en este caso se trata de una familia de extrema derecha. El personaje del novio, agradecido por la invitación aunque aturdido por el comportamiento de los miembros de la familia, trata de escapar del ámbito familiar, grotesco y hostil, pero no lo consigue. El autor muestra una prolongación de la vida cotidiana, deformada poéticamente, conservando una imagen familiar que le resulta próxima y que sitúa en un espejo del tiempo para hacernos reflexionar. En la última acotación podemos leer:

(El novio se dispone a marcharse, pero entonces la novia lo coge del brazo y se lo lleva al centro de la escena, al centro de la familia, porque después de todo allí va a haber dentro de poco un almuerzo, un almuerzo familiar, un almuerzo con toda la familia, la amada familia portadora del emblema y portadora de la sangre, la familia. El padre, que sigue sin quitarle ojo, mecánicamente, vuelve a tenderle la mano. Todo es tan frío que se congela.) (Palacios 1999a: 15).

Serenos ${ }^{10}$, es una obra abierta y abstracta, enmarcada dentro de un paradigma más poético, con reminiscencias lorquianas por ejemplo en cuanto al tratamiento del ritmo, donde las palabras se repiten cercanas a la letanía: "El aire es frío-el aire me raja la cara-Hay gaviotas que vuelan por la noche-sus alas son navajasnavajas que no se clavan-navajas que rajan-navajas que rajan-navajas que rajan..." (Palacios 1999b: 4).

Y por último El muro, que en cierta medida podríamos decir que es una deconstrucción de Romeo y Julieta, un romance poético en forma de duelo entre Píramo y Tisbe que muestra temáticas como el cortejo, el amor destinado a un posible fracaso, la percepción del tiempo, el dilema moral que cuestiona la lealtad al amor o el miedo a los designios desafortunados. Si hay algo que destaca, sobre manera, es su poética verbal:

10 El autor incluye esta obra como uno de los cuadros que componen Tatuaje (obra escrita para danza-teatro), estrenada en 1998. 
Tisbe: ¿Por qué huyes?

Píramo: Porque quiero quedarme

Tisbe: Si te vas me dejarás el hueco del cuchillo en el pecho.

Píramo: Si me quedo te sembraré los pasos de sal [...] te amaré, me amarás y luego nos vencerá el tedio y perderemos lo que fuimos...

Tisbe: Lo que somos.

Ṕ́ramo: Se perderán las caricias, se perderán los latidos. Cada mañana tendré que odiarte un poco más $[\ldots]$

Tisbe: Me dejarás de amar.

Píramo: Te amaré, te amaré como se ama algo gastado de tanto amarlo [...]

Tisbe: En este laberinto ha de haber una salida; una al menos, una. Ayúdame a encontrarla.

Píramo: No la hay [...] Nuestros nombres están malditos [...]

Tisbe: para ti siempre es de noche.

PírAmo: mañana moriremos.

TISBE: mañana es una mentira... (Palacios 1999c: 2-7 ).

De su obra El Ídolo, escrita en 1999 y reescrita en 2015, destacamos la relevancia argumental que confiere a los personajes Lady Desire y Blanna, seres desolados, solitarios, fragmentados y misteriosos, soñadores de un amor irreal, de una felicidad inalcanzable. La forma en que son utilizados los recursos dramáticos genera una gran tensión, aparece el sexo como pulsión de vida y placer, el amor desconsiderado como puerta hacia la decadencia y la muerte. Abundan las alusiones pictóricas, a Lautrec y Rodin principalmente; y literarias, en especial a La Divina Comedia.

Prosigue con El hombre del saco (1999), Accésit de la III edición del premio Romero Esteo, que fue dirigida por José Antonio Sedeño para Factoría Zulú y estrenada en el verano del 2000 en Málaga. Es una obra dividida en 20 episodios, incluido el epílogo, pensada para cinco actores, con 13 personajes más un coro de poetas. A través del personaje Cicerón, su protagonista, el autor reflexiona sobre la concepción de la belleza de Rodin, sobre la destrucción de la belleza, más hermosa que la propia belleza (Arribas 2018). Aquí el autor sintetiza su visión del compromiso, la idea de lo que debe ser un artista comprometido y evidencia una clara influencia poética que, en ocasiones, nos remite a Luces de Bohemia. Curiosamente, el desenlace es positivo, algo poco usual en las obras de este autor.

Tanto El Ídolo como El hombre del saco, muestran una pequeña ruptura en su escritura por un uso de estilo que podríamos definir como "expresionismo de realismo", un tanto experimental y vanguardista aún pero donde el autor ya muestra un dominio mucho mayor de su expresión propia. Ambas obras comparten que fueron producto de su estancia en el Traverse Theatre. 
Hasta este tiempo, la producción de Palacios es llevada a la escena con éxito e incluso algunas de sus obras son premiadas ${ }^{11}$, sin embargo, paradójicamente su teatro no es programado en las redes teatrales como se merece, seguramente por ser demasiado comprometido y por utilizar un lenguaje que desconcierta al público comercial, acomodado y sediento de cabeceras de cartel o más bien, por las mentalidades de empresarios y programadores. Descontento por no poder continuar con una actividad teatral activa en la escena, Palacios solicita una beca para irse a vivir a Francia.

Durante su estancia en este país (octubre 2000-agosto 2009), trabaja como auxiliar de español en un instituto de enseñanza media, como lector en una Universidad pública, para Instituciones y Universidades privadas impartiendo clases de lengua y literatura, o dirigiendo el Departamento de Relaciones Internacionales. Es una época en la que escribe mucha narrativa ${ }^{12}$. Son años en los que apenas escribe teatro y se desliga de la escena hasta que funda en el 2002 un laboratorio teatral, Théâtre Zéro, que perdurará hasta su regreso a España.

Con La decepción del pequeño Julius Mannetari (2004) Palacios comienza a incluir elementos y premisas del teatro posdramático de una manera consciente sobre el texto, con un uso de la estructura vertical y de la simultaneidad. Una obra sincera, honesta y con muchísima potencia, que escribe porque el autor Javier Berger le pide un texto para una revista que finalmente no vio la luz. Más tarde, esta obra sería publicada en la revista Contraluz (2011).

La Reunión (2005) es una obra atípica, una comedia realista que roza el vaudeville. Se trata de una reunión de amigos que llevan la derrota tatuada en la mirada, con numerosos personajes e infinidad de entradas y salidas, como corresponde al género. Entre los temas centrales destaca el conflicto entre arte y mercado en el contexto del teatro. En palabras del autor:

Utilizando el tópico de los amigos que se ven diez años más tarde, y apoyándome en la evocación del Accionismo Vienés, di forma a este vaudeville con la rabia del que presencia un crimen y no puede hacer nada para evitarlo. Ese crimen es la muerte de las artes teatrales a manos de las instituciones públicas, por su pasividad y su ignorancia, y del mercado, por su voracidad y la cobardía de sus actuantes (Chabassier 2013: 1).

En 2007 escribe Europa Light, muy comprometida, con tintes épicos y que nos habla sobre la guerra y sobre la frivolidad con la que vemos el tercer mundo desde la gran Europa. Según apunta Pedro Ruiz, "La obra se sitúa ante la posmodernidad, la del capitalismo en su última fase, la de una realidad fluida en la que lo global solo afecta a los mercados, no a las personas" (Ruiz 2016). Es un teatro de denuncia y de urgencia. Interesante señalar que muchos de sus cuadros

11 En Junio de 1999 viaja a Roma invitado a la Bienal del Arte Mediterráneo por haber ganado la Muestra de Artes Escénicas en Málaga.

$12 \mathrm{Su}$ novela Tierra de Nada (publicada como Los adoradores de la serpiente roja, Girona, Luces de Gálibo, 2014) fue finalista al Premio Internacional Minotauro de Novela Fantástica y de Terror en 2010. 
-en total, 22 más un epílogo- reflejan una noticia real documentada en prensa, lo que permite al autor elaborar la crítica de un sistema inhumano y absurdo a través de los juegos de una estructura densa que va tejiendo hábilmente unas relaciones que nunca se explican del todo (Ibídem).

En su forma alterna ambientes lingüísticos diversos, destacando entre los componentes narrativos tres registros principales; el lenguaje coloquial para el caso de la fábrica, el absurdo y grotesco presente en los soldados, "Numerosas repeticiones, logorreas y aberraciones sintácticas se combinan con elementos de caricatura a nivel fonético o semántico" (Ibídem: 5) y otro más poético casi lírico que es el utilizado por los amantes.

El tiempo y el espacio se diluyen para aumentar la tensión en los sucesos y los personajes, anónimos, muestran una identidad que "se resuelve en el discurso, entre el vacío y la zafiedad o un lirismo imposible" (Ruiz 2016: 3) creando momentos de identificación y otros de distanciamiento. La obra mantiene una estructura de mosaico, un conjunto de fragmentos con la estética de la discontinuidad y la fractura. "En la primera escena ("episodio"), una violación. En el epílogo, un linchamiento (o por lo menos están a punto de). En el intervalo: la guerra humanitaria, el mercado, los refugiados, la fortaleza Europa, la exclusión, el consumo, la alienación. Palacios nos tiende un espejo en el que cuestionar la sociedad en la que vivimos y las fuerzas que la rigen" (Filleul 2015: 4). Importantes son las acotaciones fusionadas con el texto, difíciles de separar, pues informan de la organización de un posible espacio escénico, describen personajes, acciones y crean atmosferas. Una escritura concebida en clave de representación y donde muestra su sentido del espectáculo.

En 2010, un año después a su regreso a España, Palacios funda junto a otros compañeros una productora que integra dos compañías teatrales, Teatro Línea 6 y Teatro de los Orígenes Laboratorio. Por entonces, escribe una obra infantil Los grandes enigmas del Universo según la pepona Marillena.

En una estructura clásica con prólogo, 5 escenas y epílogo, esta obra nos ofrece dos visiones antagónicas del mundo, la del convencionalismo social, abanderada por el payaso ${ }^{13}$ Criecricrik, y la del misterio, defendida por la pepona Marillena. Apuntar, como dato interesante, que los protagonistas de esta obra, pepona Marillena y payaso Criecricrik, escapan de Muñecos de Buridán, aunque evidentemente su forma de actuar y expresarse está adaptada al público infantil.

Con La enjundia de los pastores ${ }^{14}$ (2012) el autor revela su compromiso como contrapoder, como resistencia desde un activismo del pensamiento y la práctica teatral. Es un drama político donde se integra el grotesco como recurso estilístico. En su estructura, 5 piezas breves entrelazan el corpus principal,

13 Los payasos son una constante en la obra del autor, convertidos en una especie de obsesión que se repite y que muestran ser reflejo de la sociedad actual.

$14 \mathrm{El}$ autor ofrece dos posibilidades para llevar la obra a escena, bien montar el texto completo o poner en escena solo el cuerpo principal, recomienda no montar piezas sueltas. 
estructurado en tres actos. El espacio y el tiempo varían; lugares indeterminados, una pista de circo, una calle, una clase de un colegio, sirven para enmarcar el drama que nos devela a su vez, lo que no sabemos ni vemos pero que puede suceder en la tarde-noche de unas elecciones generales dentro de la sede de un partido de derechas. Una obra que encierra una protesta con sentido crítico del sistema político, provocadora pero nada panfletaria y donde el autor muestra su oposición a la impunidad de los poderes dominantes.

En 2014, Palacios escribe y lleva a escena con Teatro Línea 6 dos obras para bebés. La primera, Anamakanda, es una reescritura para bebés de La Odisea. Escogió este texto por ser considerado como nuestro primer relato, por eso le pareció oportuno que también lo fuese para los bebés (Arribas 2018). Esta obra activa muchos resortes en el niño, según alude Miguel Ángel Barba al respecto en la crítica para Aforo Libre:

Buen trabajo de creación, gestión y dirección [...] los bebés y pequeños pueden experimentar todo tipo de sensaciones sonoras, visuales, táctiles, emotivas, la risa, las cosquillas, el contacto y la ternura [...] los aspectos sonoros diferencian las escenas con atmosferas heterogéneas (2014).

La segunda obra Cheshire, es una reescritura para bebés de Alicia en el país de las maravillas, un viaje mágico al mundo de las sensaciones con el gato Cheshire como guía. En esta obra, los recursos teatrales son dinámicos, abunda la estimulación visual, el lenguaje corporal, la comunicación y la interacción con los pequeños (Acquaroli 2014).

Sin olvidar las piezas creadas por el autor para danza-teatro, señalamos Los amantes del miedo (1995) o Tatuaje (1998) ambas llevadas a la escena por Thomé Araújo con Málaga Danza Teatro. En 2016, escribe conjuntamente con el bailarín y director Fernando Hurtado El paraíso de los necios, estrenada ese mismo año por la compañía del coreógrafo.

Y llegamos a la tercera etapa del autor donde prevalecen sus obras posdramáticas. En cierta medida, apunta a una búsqueda hacia una obra más abierta, con un alto interés por lo emocional sin renegar de lo intelectual, sumando grandes dosis de intuición.

En 2015 escribe Sacrificio 0.11, incluida en 2018 en un texto más amplio, Memorando sobre los borregos y las focas, centrado en el compromiso y, sobre todo, en la falta de compromiso y sus consecuencias.

En El mal supremo (2015) opta por trabajar las nociones del rol y personalidad, con alusiones a las "máscaras" como elementos que nos son impuestos. Resaltando la teatralidad, nos cuestiona sobre qué hay detrás de las máscaras, de nuestros hechos y acciones, los cuales, al igual que en los personajes, ¿revelan lo que realmente somos? o como en su caso ¿nos impiden ver al actor que está detrás? A este respecto, resulta muy significativo el momento en el que el soldado presenta los nombres de doce personas, "Me llamo..." 15 , seguido de la

15 Antes de comenzar el espectáculo, alguien de la compañía pide a las personas que 
aparición en escena del carnicero-torturador manchado de sangre, son instantes en los que la duda se impone, el azar se incluye y nos obliga a preguntarnos de qué está hablando, si de los torturadores o de las víctimas, un suspense que nos empuja a situarnos y a interrogarnos sobre quiénes somos, a reflexionar si esa crueldad en los personajes les viene dada o es un rasgo del rol que asumen en su trabajo.

El autor lo que está creando es una imagen, son elementos brechtianos -herencia del teatro del siglo XX- pensados al milímetro y descritos en las acotaciones:

([...] barbacoa roja de dominguero profesional [...] soldado alto y musculoso, con el torso desnudo [...] pantalones mimetizados, botas negras y gran machete amarrado en la pierna, sombrero de camuflaje y gafas de sol [...] una lata de cerveza de medio litro [...] nevera de playa color azul [...] un transistor en el bolsillo de su pantalón [...] la bailarina rubia de cabellos largos y cuerpo escultural.) (Palacios 2015: 2).

Con ello nos hace participes de una experiencia sensorial, estética, enigmática y emocional en la que realmente no vemos que pase nada salvo cuando llega el momento en el que el soldado, frente al público y de manera ambigua, comienza a decir nombres. En esta obra, Palacios desplaza el conflicto, que ya no se encuentra en la acción que estamos presenciando en escena, sino que se establece entre la escena y los espectadores.

Con El círculo de tiza y la raya de sal (2015), el autor comparte una obsesión por lo espiritual, por lo humano, desde lo social. Nuevamente, hace alusión a las máscaras, como en Mascarada o El mal supremo, revelándose como una constante en su escritura, un signo de identidad de su obra. Esta referencia a las máscaras nos remite a Jodorowsky, a la idea de los falsos rostros que ocultan la verdad y realidad de cada cual, pero también a Gurdjieff, que es mencionado explícitamente en el texto.

La herencia de Auschwitz (2017) es un trabajo que el autor desarrolla en plena crisis, marca un punto de inflexión en su dramaturgia y se observa un interés por la forma de expresión escrita con una intención por profundizar de manera especular en la historia. De estructura abismada, compleja, nos presenta el teatro dentro del teatro al igual que hizo anteriormente en Mascarada, o en La puerta, los cuervos... Sin ser una obra realista, el autor nos traduce la realidad precaria del mercado laboral reflejada en la desesperación del desempleado, altamente cualificado, sometido a cuestionarios inútiles manejados por empleados públicos que deciden su futuro. Con sucesos que aluden al campo de Auschwitz-Birkenau, con textos en alemán que vertebran la obra, con reminiscencias circenses y sacras en la música, con el uso del recurso de la simultaneidad, el autor nos invita a cuestionarnos cuál es la realidad, si la del final o la del principio de la

componen el público rellenar una ficha en la reflejen tres datos personales: nombre y apellidos, lugar y fecha de nacimiento más la profesión real para la que están preparados y hacen o les gustaría hacer. 
obra o si son dos realidades yuxtapuestas ya que los personajes son los mismos; la empleada de la agencia pública de empleo, el desempleado y un tipo muy gris que acaba revelándose como un kapo del campo de exterminio.

Condicionamiento operante del melodioso ladrido del perro pastor español (2017) es un reflejo de los asuntos sin resolver que continúan acentuando la crisis del país, hechos que reflejan estar en un periodo de involución humana. El personaje, en un monólogo cómico con humor e ironía como recurso, narra al detalle la matanza de un marrano con reminiscencias históricas, alusiones a fosas comunes y enterramientos colectivos. No deja de recordarnos metafóricamente que "el que tiene el cuchillo tienen el poder, el guarro es carne de matanza, sin el guarro no hay matanza, la matanza es necesaria para que el matarife funcione, la matanza es necesaria para mantener el poder" (Palacios 2017). El sexo como tema recurrente, el striptease, las evocaciones históricas y la figura del payaso son recursos que sirven al autor para retratar al individuo de hoy que se debe, parece ser, "tanto al personaje que le ha tocado en suerte como a la coyuntura en la que vive" (Arribas 2018).

Señalar que las obras puramente posdramáticas La tentación del pequeño Julius Mannetari, Memorando sobre los borregos y las focas y Condicionamiento operante del melodioso ladrido del perro pastor español son tratadas como un viaje, como una experiencia a través de los sentidos y constituyen una especie de retablo sobre las raíces del autor que desvelan cómo siente la realidad de este país, desde los ecos del franquismo presente en su adolescencia, pasando por las crisis políticas que azotan el país hasta su visión de la deshumanización que caracteriza una sociedad enfermiza como la nuestra.

Finalmente, he de citar las obras que Palacios escribe sobre la escena, y las performances. En una primera etapa escribe La Pecera ${ }^{16}$ (1997), La retórica del azul (1997) y Trastos (2000) escritas sobre la escena de manera tridimensional.

En Francia, aborda Mapas (2001), acciones performáticas como Action 0.1. (2006) y Action 0.3. (2007) y dos reescrituras posdramáticas: L'Age du Sanglier (sobre Ricardo III de Shakespeare) y Agamenón 09 (sobre Agamenón de Esquilo).

Entre 2010/12 desarrolla la serie $\mathrm{PH}^{17}$, marcada por el azar y la dramaturgia de la complejidad, en la que recorre el camino de la performance al teatro posdramático. En espacios distintos y alternativos a los habituales, pero también en teatros convencionales, se mostraron las diferentes piezas que componen estas "ceremonias", con la catarsis de fondo, para reflejar la preocupación por

16 Obra posdramática con la que gana el Premio de Artes Escénicas en las Muestras Culturales Ciudad de Málaga en 1998; y el Premio a la Compañía Revelación otorgado por el Teatro Cánovas también de Málaga, el mismo año.

17 PH1, PH2 y PH3 (Rituales del mundo biológico), PH4 Ritual del mundo biológico, PH5 Rituario, PH6 Liturgias de la abrupta nada y la formidable oscuridad, PH0-7 Pequeño estudio para un retrato, PH8 Les liturgies du déjeuner, PH9 Del corazón perdido en el laberinto de las oficinas, PH10 Liturgias de los mapas, PH11 Ritual del reflejo y su reflejo, PH12 Ritual de lo visible y lo invisible, PH13 Liturgias de la nada, PH14 Génesis. 
el ser humano y la búsqueda de la felicidad. El resultado es un diálogo con el público, midiendo fuerzas a modo de pulso, con un empeño por seguir a los personajes que luchan en el espacio con sus frustraciones. Obras con un enfoque multidisciplinar, que adquieren una gran poesía escénica por el tratamiento que el autor hace del tiempo, el espacio y el movimiento.

Los cuatro primeros $\mathrm{PH}$ le sirven al autor como experimentación sobre la performance y el azar, pero a partir de ahí, su dramaturgia se vuelve más compleja, regresando a un terreno practicado por él desde La pecera (1997) en el que la imagen y el texto dialogan para construir el sentido y tienen la misma importancia, y el azar solo aparece en momentos imprevistos, pues todo funciona como una verdadera maquinaria de relojería. Por ejemplo, en PH8 Les liturgies $d u$ déjeuner (2011) el autor asume una hiperestética en un espectáculo que cuestiona, tortura y apasiona: "ultra vivo, brillante, conceptual y perturbador" (Dionot 2011) y concretamente en PH14 Génesis hace un uso de herramientas múltiples, "navega entre lo gestual y lo textual, tomando elementos de la danza, acompañados de una teatralidad con ligeras dosis expresionistas. Los textos vislumbran una poética descarnada, reiteración y ruptura es una constante que hilvana estas performances conformando un todo" (Baquero 2012).

En 2013, reescribe El príncipe constante de Calderón bajo el título de Konstante 013. Según apunta Françoise Chabassier (2013b), "Palacios se fija especialmente en la estructura, en el papel de los ritos en la obra de Calderón. La desestructura para luego reconstruirla. Quiere ir a la esencia de la obra original o sea la esencia del rito". Por otro lado, Martín Moriche en el Diario Sur señala, "Las diferentes escenas están desarrolladas de una manera tan directa y sin dobleces, que la crudeza de muchas de ellas da de lleno en la sensibilidad y el corazón del espectador. Es teatro desnudo y sin concesiones, tan verdadero y lleno de razón que no hay lugar al artificio" (2013).

Más tarde, Palacios lleva a cabo junto a Leslie Sánchez un trabajo conjunto performativo titulado Los límites y el caos (De lo cósmico a lo cómico), estrenado en 2015 en el hall de la Facultad de Derecho de Málaga, en donde dieciocho años antes, Sánchez y Palacios iniciaron su andadura juntos, en el marco de una exposición de escultura del primero, El porvenir de los tréboles, para la que Palacios realizó el espectáculo performático y posdramático, La retórica del azul.

A modo de conclusión podemos señalar que Palacios es un hombre comprometido con el teatro y con su tiempo, las circunstancias históricas y políticas repercuten en su obra, teñida por un fuerte cariz ideológico, metafórico y metafísico. Su escritura busca la provocación, siempre presente, en unas estructuras y vitalidad estilística que rompen los esquemas lógicos del espectador.

Profundiza en aspectos únicos de nuestra propia experiencia aportando a la creación escénica su personal visión del mundo, de ahí, que en su trayectoria haya una necesidad de ser consciente de que el "yo", el individuo, tiene necesidad de hablar, expresarse, comunicar... en un entorno que se constituye con una 
gran cantidad de sistemas establecidos y considerados como "perfectos", pero que tampoco lo son. Un entorno, un mundo, que más tarde considera un caos y en donde observa una disociación entre realidad y verdad que siempre andan en confusión. Esa lucha constante entre realidad y verdad, ese mundo regido por un orden aparentemente ideal, son elementos que influyen en su vida y que transporta a su obra.

Como autor reivindicativo, cuestiona y plantea dudas, habla de lo que ocurre sacudiendo conciencias, de nuestro entorno más inmediato en estado de crisis e ilumina nuestras contradicciones como seres humanos con el fin de transformar la realidad. Autor con regocijo crítico, de espíritu belicoso, complejo e intenso, magnético e inquietante, profundo y frívolo a la vez, es extremadamente sugestivo.

\section{Bibliografía}

Acquaroli, A., 2014, "Cheshire. Teatro para bebés, en el Espacio B del Teatro Cánovas. Un viaje mágico por el universo infantil”, Aforolibre, 13/12/2014, $<$ http://www.aforolibre.com/teatro/teatro/cheshire-teatro-para-bebes-en-elespacio-b-del-teatro-canovas-1477>.

Arribas, C., 2018, “Entrevista a Miguel Palacios”, Inédita: 29 de Abril del 2018, Córdoba.

Baquero, C., 2012, "PH14 (Génesis) de Teatro de los Orígenes en el Teatro Cánovas", Aforolibre, 27/03/2012, <http://www.aforolibre.com/teatro/teatro/ ph14-performances-hilvanadas-genesis-en-el-teatro-canovas-243>.

Barba, M. Á., 2014, “Anamakanda de la Cía Línea 6. Teatro para bebés en el Teatro Cánovas", Aforolibre, 09/02/2014, <http://www.aforolibre.com/ teatro/teatro/anamarkanda-de-la-cia-linea-6-teatro-para-bebes-en-el-teatrocanovas-1146>.

Chabassier, F., 2013, "La Reunión de Teatro Línea 6 llega al Teatro Cánovas", Aforolibre, 02/02/2013, <http://www.aforolibre.com/teatro/teatro/la-reunionde-teatro-linea-6-llega-al-teatro-canovas-624>.

Chabassier, F., 2013, “Constante 013, de Producciones Teatro de los Orígenes en la Sala Gades", Aforolibre, 02/03/2013, <http://www.aforolibre.com/teatro/ constante-013-de-produciones-teatro-de-los-origenes-en-la-sala-gades-662> .

Díaz, J. A., 2018, "Maruja. Un texto contundente y sin fisuras", Diario de Córdoba, 23/02/2018, <http://www.diariocordoba.com/noticias/cultura/ maruja_1208102.html>.

Dionot, A. S., 2011, "PH 8 Les liturgies du déjeuner", Nouvelles repliques, 23/07/2011, <http://nouvellesrepliques.over-blog.com/article-ph8-lesliturgies-du-dejeuner-80072821.html $>$.

Filleul, F., 2015, "Prólogo", en: Palacios, M., 2015, Europa Light, Sevilla, Centro de Documentación de las Artes Escénicas de Andalucía, p. 4-6.

Martín Moniche, S., 2013, “Teatro y compromiso”, Diario Sur, 05/03/2013, p. 41. Palacios, M., 2015, Europa Light, Sevilla, Centro de Documentación de las Artes Escénicas de Andalucía. 
Palacios, M., 2011, La decepciòn del pequeño Julius Mannetari, Contraluz, Revista de Investigación Teatral de ESAD Málaga, n 5, 02/2011, p. 254-265.

Palacios, M., 1995a, La otra orilla del carbono, Málaga, Árbol de Poe.

Palacios, M., 2014, Los adoradores de la serpiente roja, Girona, Luces de Gálibo.

Palacios, M., 2007, "Influence de la recherche et des arts plastiques dans les activités de Théâtre Zéro", en: Danetis, D., 2007, Pratiques artistiques, pratiques de recherche, Paris, l'Harmattan, p. 273-286.

Palacios, M., 1995b, Mascarada de San demonio mártir y la vieja pelleja, inédita.

Palacios, M.,1995c, Maruja, asesina de mosquitos, ratas, torturadores y verdugos, inédita.

Palacios, M., 1996, Muñecos de Buridán, inédita.

Palacios, M., 1998, El paraíso terrenal, inédita.

Palacios, M., 1999a, El almuerzo familiar, inédita.

Palacios, M., 1999b, Serenos, inédita.

Palacios, M.,1999c, El muro, inédita.

Palacios, M., 2015, El mal supremo, inédita.

Palacios, M., 2017, Condicionamiento operante del melodioso ladrido del perro pastor español, inédita.

Romojaro, R., 2011, “Miguel Romero Esteo, de la vanguardia a los orígenes”, Campo de Agramante, $\mathrm{n}^{\circ}$ 15, primavera-verano 2011, <http://www.cervantesvirtual. com/nd/ark:/59851/bmcnp418file://C:/Users/Usuario/Downloads/miguelromero-esteo-de-la-vanguardia-a-los-origenes.pdf $>$.

Ruiz, P., 2016, "Presentación de Europa light", inédito, Facultad de Filosofía y Letras, 10/12/2016. 